\title{
Utilization of Edamame (Glycine max (L.) Merr) And Red Bean (Phaseolus vulgaris) As A Functional Beverage
}

\author{
Melanie Cornelia, Soraya Triesly Lessy \\ Department of Food Technology, Faculty of Science and Technology, Pelita Harapan University, UPH Tower, $B$ \\ Building, Karawaci, Tangerang 15811 Indonesia \\ ${ }^{*}$ Corresponding author. Email Addresses: melanie.cornelia@uph.edu
}

Received August 18, 2017; Accepted December 9, 2017

\begin{abstract}
Indonesia had the big potency to produce red beans and edamame beans, but its utilization regarding functional food was not optimal. This research was intended for development combining red and edamame beans to become a new functional beverage product. The ratio of edamame milk to red bean milk (100:0, 75:25, and 50:50) and cooking temperature $90{ }^{\circ} \mathrm{C}$ has been selected based on SNI soymilk. During storage, a phase separation happened. Consequently, stabilizer should be added to improve its stability. Three types of stabilizers were used,CMC $0.1 \%, 0.2 \%$, and $0.3 \%$, xanthan gum (XG), and guar gum (GG) $0.025 \%, 0.05 \%$, and $0.1 \%$, respectively. The best formulation was milk ratio $75: 25$ with $90{ }^{\circ} \mathrm{C}$ and addition of XG $0.05 \%$. The dietary fiber analysis for milk formulation was $4.46 \%$ therefore it was categorized as a functional beverage.
\end{abstract}

Keywords: dietary fiber, edamame, red bean, functional beverage, xanthan gum.

\begin{abstract}
ABSTRAK
Produksi kacang merah dan kedelai Indonesia sangat potensial, namun pemanfaatannya sebagai pangan fungsional masih kurang. Penelitian ini bertujuan untuk mengembangkan kacang merah dan kedelai sebagai produk baru makanan kemasan. Perbandingan antara susu kacang merah dan kedelai (100:0, 75:25, and 50:50) dan temperatur pemanasan 90 ${ }^{\circ} \mathrm{C}$ telah dipilih berdasarkan SNI. Selama proses penyimpanan terjadi fasa pemisahan sehingga senyawa penstabil perlu ditambahkan. Tiga tipe stabilizer yang digunakan adalah CMC $0.1 \%, 0.2 \%$, dan $0.3 \%$, xanthan gum (XG), dan guar gum (GG) $0.025 \%, 0.05 \%$, and $0.1 \%$. Formulasi susu terbaik diperoleh dengan perbandingan $75: 25$ pada suhu $90{ }^{\circ} \mathrm{C}$ dan penambahan XG $0.05 \%$. Analisis serat makanan formula susu menunjukkan 4,46\% sehingga dapat dikateogikan sebagai pangan fungsional.
\end{abstract}

Kata kunci: serat makanan, kedelai, kacang merah, pangan fungsional, xanthan gum.

\section{INTRODUCTION}

Edamame beans (Glycine max L. Merr) and red beans (Phaseolus vulgaris) were high in protein and food fiber. Edamame beans contain high protein 10.0-10.9 grams or equivalent to $22 \%$ daily intake and food fiber contained as much as $5.2-6.82$ grams in 100 grams [1,2], which meet the requirements of high-protein foods (foods with protein exceeding $20 \%$ of daily energy value) and sources of dietary fiber (foods that exceed 3 grams per 100 grams). In addition, edamame nuts were also contained many vitamins and minerals, such as iron, calcium, potassium, phosphorus, magnesium, folate, vitamins $A, B 1, B 2, B 3, C, E$, and $K$ [3]. Edamame in Indonesia located in soybean barn, Jember (East Java) were $42 \%$ of national soybean production. People consume 100 grams of legumes provide $20 \%$ protein and
$10 \%$ dietary fiber per day [4]. Nowadays, red beans were processed to be soup, and complement dessert, but people tend not to consume red beans because of its unpleasant smell. In addition, protein content of edamame is higher than red bean. Therefore, this research studies the possibility for functional food development by combining red beans and edamame beans to create a new functional beverage product. Soymilk was a water extract of soybean, with or without permitted additive. However, during storage, a phase separation occurred, consequently, the stabilizer was often added to improve its stability. In this research, the ratio of edamame milk to red bean milk and cooking temperature with addition of stabilizer has been observed. 


\section{MATERIALS AND METHODS}

The raw materials were used edamame bean, red bean, and drinking water. Chemical were used such as $\mathrm{H} 2 \mathrm{SO} 4, \mathrm{~K} 2 \mathrm{SO} 4, \mathrm{NaOH} 50 \%$ (w/v), $\mathrm{NaOH} 4 \mathrm{~N}$, boric acid, $\mathrm{H} 2 \mathrm{O} 2, \mathrm{HCl} 0,2 \mathrm{~N}$ and hexane.The equipments were used analytical balances, blender, stove, stainless steel pan, desiccator, thermometer, furnace, soxhlet apparatus, viscometer, $\mathrm{pH}$ meter, and equipment for protein analysis (Kjeldahl).

\section{Research Stages}

This research was divided into two stages. Stage 1 began with the production of edamame milk (Fig. 1) and red bean milk (Fig.2). Research stage 1 was aimed to select three ratio of edamame milk (EM): red bean milk (RBM) and one optimum cooking temperature that refer to soymilk quality standard (SNI 01-3830-1995) [5]. The production of red bean milk based on modified procedure from Sharma et al., [6], whereas the production Edamame Milk applied the modified procedure by Onourah et al., [7] dan Angraini \& Yunianta [8.]

Research stage 2 was done to determine the most effective stabilizer to improve the stability of edamame and red bean milk functional beverage. Three types of stabilizers (CMC, xanthan gum (XG), and guar gum (GG)) were used independently to each ratio selected. CMC were added by $0.1 \%, 0.2 \%$, and $0.3 \%$, while XG and GG $0.025 \%, 0.05 \%$, and $0.1 \%$. These selected formulations were analyzed for hedonic test and dietary fiber. The beverage with the most preferred formula was selected for proximate analysis and observation of the shelf-life. Proximate Analysis of Raw Material was depicted in Table 1 and Table 2.

Table 1. Proximate analysis of edamame bean

\begin{tabular}{llr}
\hline Parameter & $\begin{array}{l}\text { Edamame Bean } \\
\text { [2] }\end{array}$ & $\begin{array}{c}\text { Fresh } \\
\text { Edamame } \\
\text { Bean }\end{array}$ \\
\hline Water (\%) & 71.35 & $65.68 \pm 1.55$ \\
Protein(\%) & 12.95 & $11.80 \pm 1.24$ \\
Fat(\%) & 5.20 & $3.53 \pm 0.48$ \\
Ash(\%) & 1.27 & $1.80 \pm 0.19$ \\
Carbohydrate(\%) & 10.50 & $17.20 \pm 2.53$ \\
\hline
\end{tabular}

Table 2. Proximate analysis of red bean

\begin{tabular}{llr}
\hline Parameter & $\begin{array}{l}\text { Red Bean } \\
{[2]}\end{array}$ & $\begin{array}{c}\text { Fresh Red } \\
\text { Bean }\end{array}$ \\
\hline Water (\%) & 66.94 & $56.61 \pm 0.69$ \\
Protein(\%) & 8.67 & $10.15 \pm 0.80$ \\
Fat(\%) & 0.50 & $1.93 \pm 0.48$ \\
Ash(\%) & 1.09 & $1.99 \pm 0.24$ \\
Carbohydrate(\%) & 22.80 & $29.33 \pm 1.67$ \\
\hline
\end{tabular}

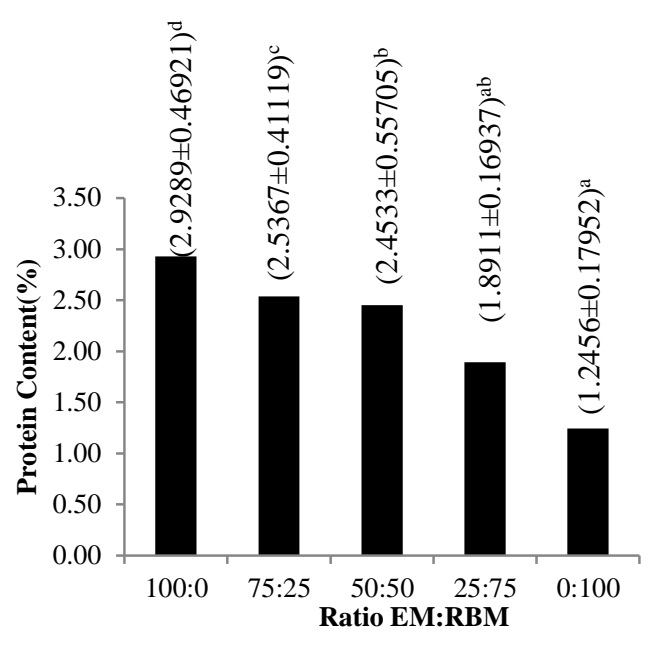

Figure 3. Ratio of EM : RBM versus protein content

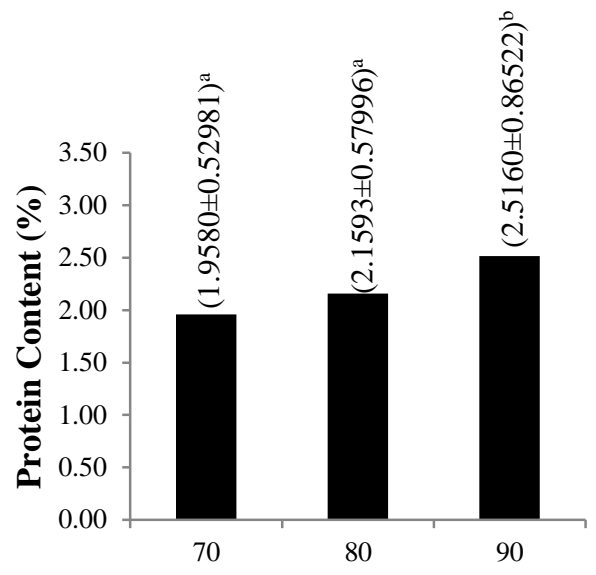

Cooking temperature (oC)

Figure 4. Cooking temperature versus protein content. Different superscript notation letter shows significant difference $(p<0.05)$

\section{RESULT AND DISCUSSION}

\section{Effect of Ratio Edamame Milk (EM) to Red Bean Milk (RBM) and Cooking Temperature toward protein content}

The result of statistical analysis showed that there was a significant different $(p<0.05)$ on ratio EM to RBM and cooking temperature towards protein content. However, there was not a significant different on interaction between ratio EM to RBM and cooking temperature.

The higher protein content obtained from $100 \%$ EM. This was due to the protein content of edamame bean $(11.80 \%)$ was higher than red bean $(10.15 \%)$. Fig 4 showed that higher cooking temperature gave the higher protein content. Cooking $90{ }^{\circ} \mathrm{C}$ obtained the 
highest protein content. Shurtleff and Ayogi [5] explained that cooking temperature at $90{ }^{\circ} \mathrm{C}$ could increase the quality of sensory and nutrition of the soymilk

\section{Effect Ratio Edamame Milk to Red Bean Milk and Cooking Temperature to Total Solid and $\mathrm{pH}$ of Edamame and Red Bean Milk}

The result showed that there was significant different of ratio edamame milk to red bean milk, cooking temperature, and interaction between these factors. Figure 5 showed that the highest total solid obtained from EM : RBM of $50: 50$, then $100: 0$ and $75: 25$ with the cooking temperature is $90{ }^{\circ} \mathrm{C}$. Based on soymilk quality standard (SNI 01-3830-1995), the total solid must be achieved min. $11.50 \%$. Total solid at $90{ }^{\circ} \mathrm{C}$ is achieved about $9.89 \%-17.90 \%$. The higher cooking temperature gives higher total solid.

The result Fig 6 showed that there was no significant difference of $\mathrm{pH}$ in each treatment. The $\mathrm{pH}$ was in range $6.70 \pm 0.16-6.75 \pm 0.16$. The production of edamame milk and red bean milk did not give any effect in $\mathrm{pH}$. Based on quality requirements of soy milk (SNI 013830-1995), pH 6.5-7.0 should be achieved [5].

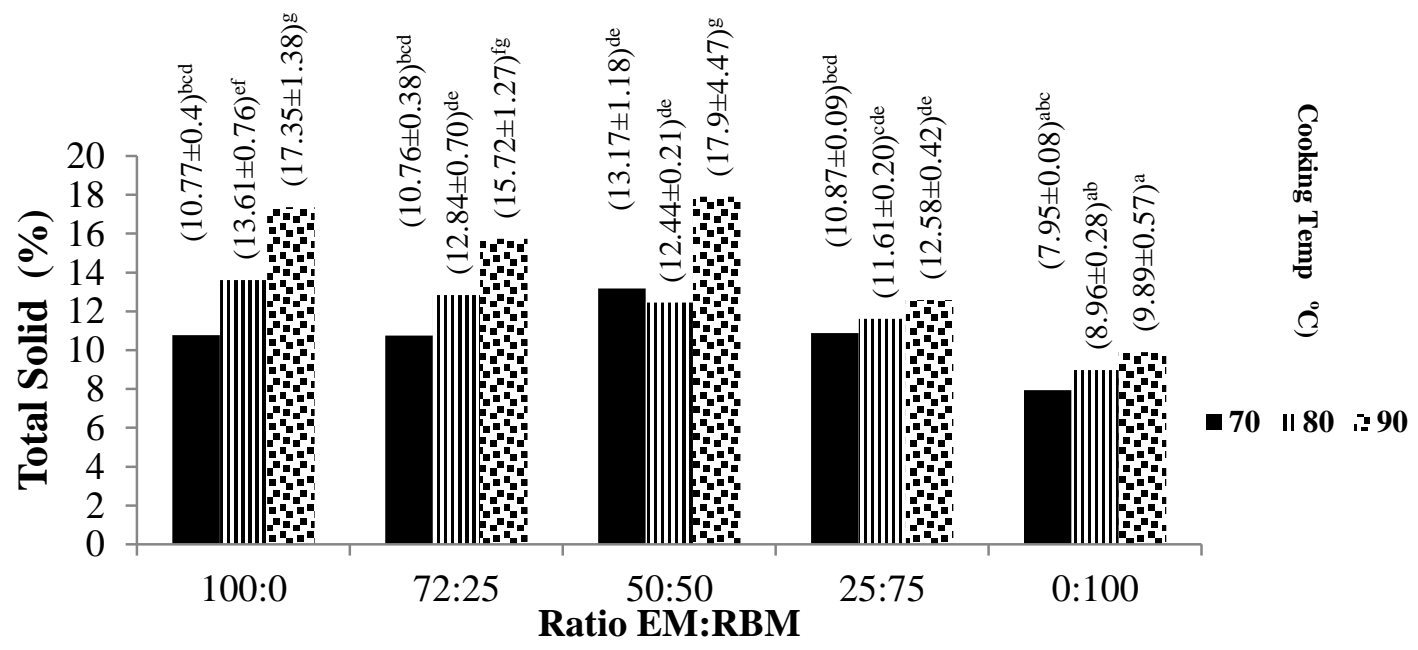

Figure 5. Ratio EM : RBM and Cooking Temp towards Total Solid. Different superscript notation letter shows significant difference $(p<0.05)$

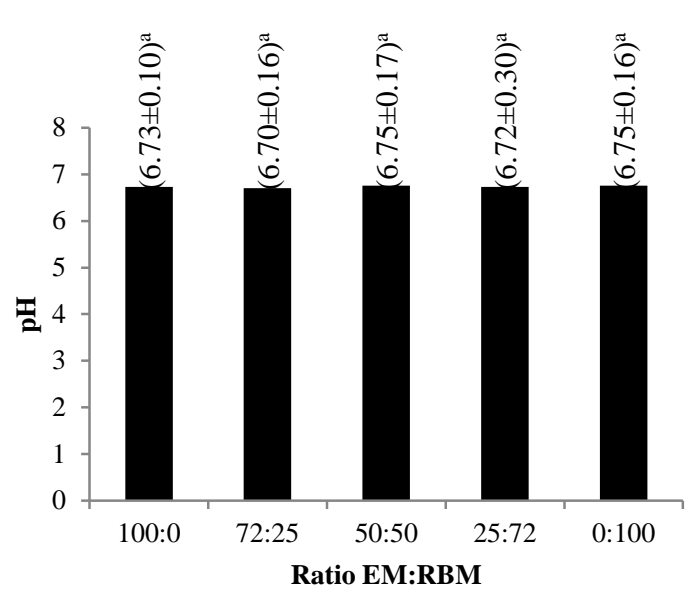

Figure 6. Ratio EM : RBM towards pH

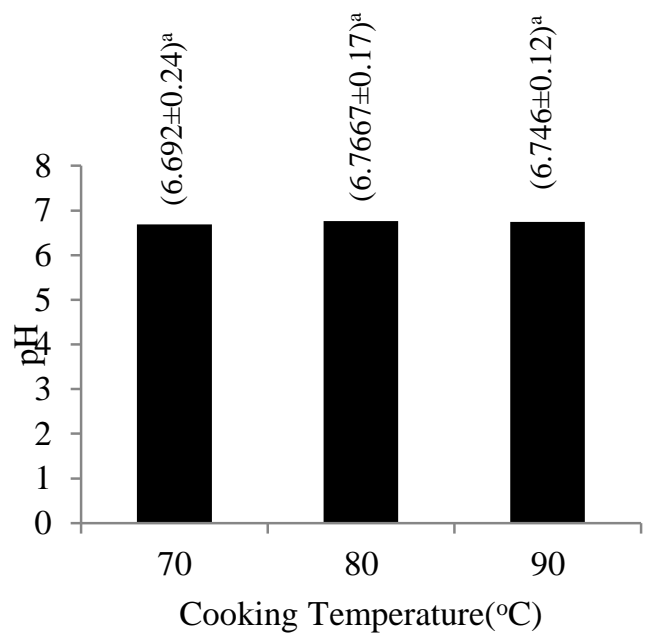

Figure 7. Cooking temperature towards $\mathrm{pH}$ 
Effect Ratio Edamame Milk to Red Bean Milk and Cooking Temperature to Viscosity of Edamame and Red Bean Milk

The statistical analysis result showed that the ratio EM to RBM and cooking temperature gave a significant effect $(p<0.05)$. There was a significant difference on cooking temperature towards viscosity, shown in Fig 9. The cooking temperature at $70^{\circ} \mathrm{C}$ $(67.120 \pm 6.3803)$ gives higher viscosity compared to $90^{\circ} \mathrm{C}(61.033 \pm 7.9289)$. This result was in accordance to Shurtleff and Aoyagi [1] in which stated that if the cooking temperature increase, could decrease the viscosity.

\section{Determination of Type and Concentration of Stabilizer towards Stability of Edamame and Red Bean Milk}

Three types of stabilizers CMC, xanthan gum $(X G)$, and guar gum (GG)) were used independently to three selected formulations from research stage 1. CMC were added by $0.1 \%, 0.2 \%$, and $0.3 \%$, while $X G$ and GG were added by $0.025 \%, 0.05 \%$, and $0.1 \%$. Finally, XG was selected to be used in formulation with different ratio of edamame milk and red bean milk. Those are 100: 0 , $75: 25$, and $50: 50$ with $X G$ addition by $0.025 \%, 0.05 \%$, and $0.1 \%$. XG provided good solubility over the temperature range freezing to near boiling with excellent thermal stability [6]. This statement supported the production of the beverage at $90{ }^{\circ} \mathrm{C}$ as an optimum cooking temperature.

\section{Determination of the Most Preferred Formulation by Hedonic Test}

The beverages that had already stable were subjected to hedonic test. There are 5 different parameters including color, aroma, taste, mouthfeel, and overall acceptance. 80 panelist were given by three formulations with optimum stability. Those are EM:RBM 100: 0; 75:25; and 50:50 with XG $0.025 \%, 0.05 \%$, and $0.1 \%$. According to the result, the different formulations

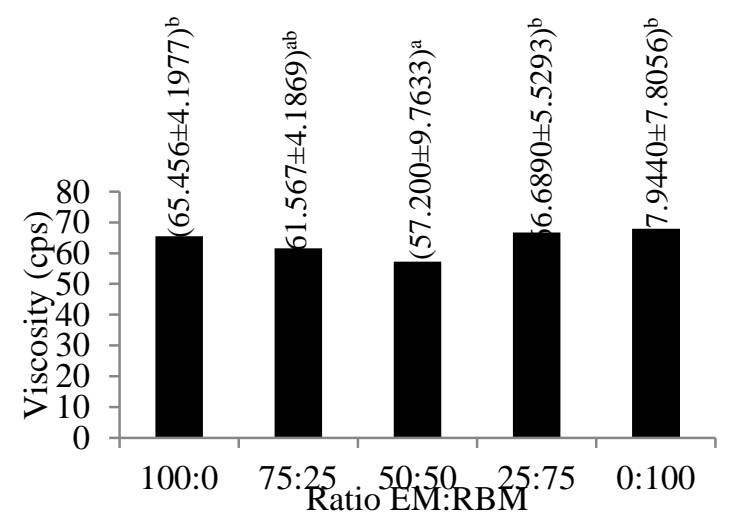

Figure 8. Ratio EM:RBM towards Viscosity (cps) gave a significant effect toward the color preference of the functional beverage. Based on the result obtained, the beverage with ratio EM : RBM of 75:25 with XG addition by $0.05 \%$ is determined as the most preferred formulation. The selection is also based on the objective to utilization red bean regarding processed food or functional food as an innovation in functional food development.

\section{Determination of the Preferred Formulation of Functional Beverage}

Determination of the best formulation of functional beverage based on several parameters: protein, dietary fiber, $\mathrm{pH}$, total solids, and hedonic test. From the research, the best formulation was ratio EM to RBM of $75: 25$ with $90{ }^{\circ} \mathrm{C}$ as optimum cooking temperature and $X G$ added by $0.05 \%$. This formulation contain $4.46 \%$ dietary fiber and is categorized as "source of dietary fiber" since the dietary fiber was more then $3 \%$ and adequate daily intake to $17.84 \%$.

According to CAC [10], "source of dietary fiber" category means 3 grams per $100 \mathrm{ml}$ and $10-19 \%$ of daily intake. Table 8 showed the ratio between the EM and RBM functional beverage in the research with the soy milk quality standard (SNI 01-3830-1995). The purpose of these comparisons is to determine the RBM and EM functional drink made whether compliance with the standards. The results of all formulations meet the soy milk quality standard (SNI 01-3830-1995) on the total solids, protein content, and $\mathrm{pH}$. The further analysis for the preferred formulation is proximate analysis, including water, protein, ash, fat, and carbohydrate content. The result of proximate analysis in Table 9 shows the results of the best proximate analysis formulations. Protein levels and fat in the most preferred functional beverage in accordance with the soy milk quality requirements (SNI 01-3830-1995) stating that the minimum protein content $2 \%$ and minimum fat content 1 $\%[5]$.

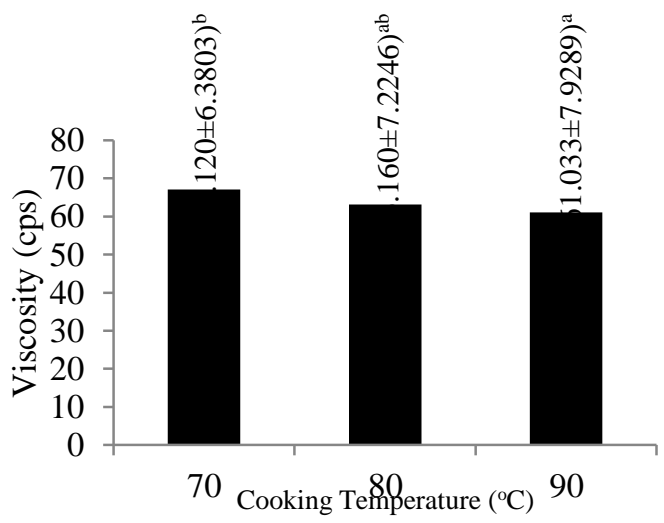

Figure 9. Cooking Temp. towards Viscosity (cps) 

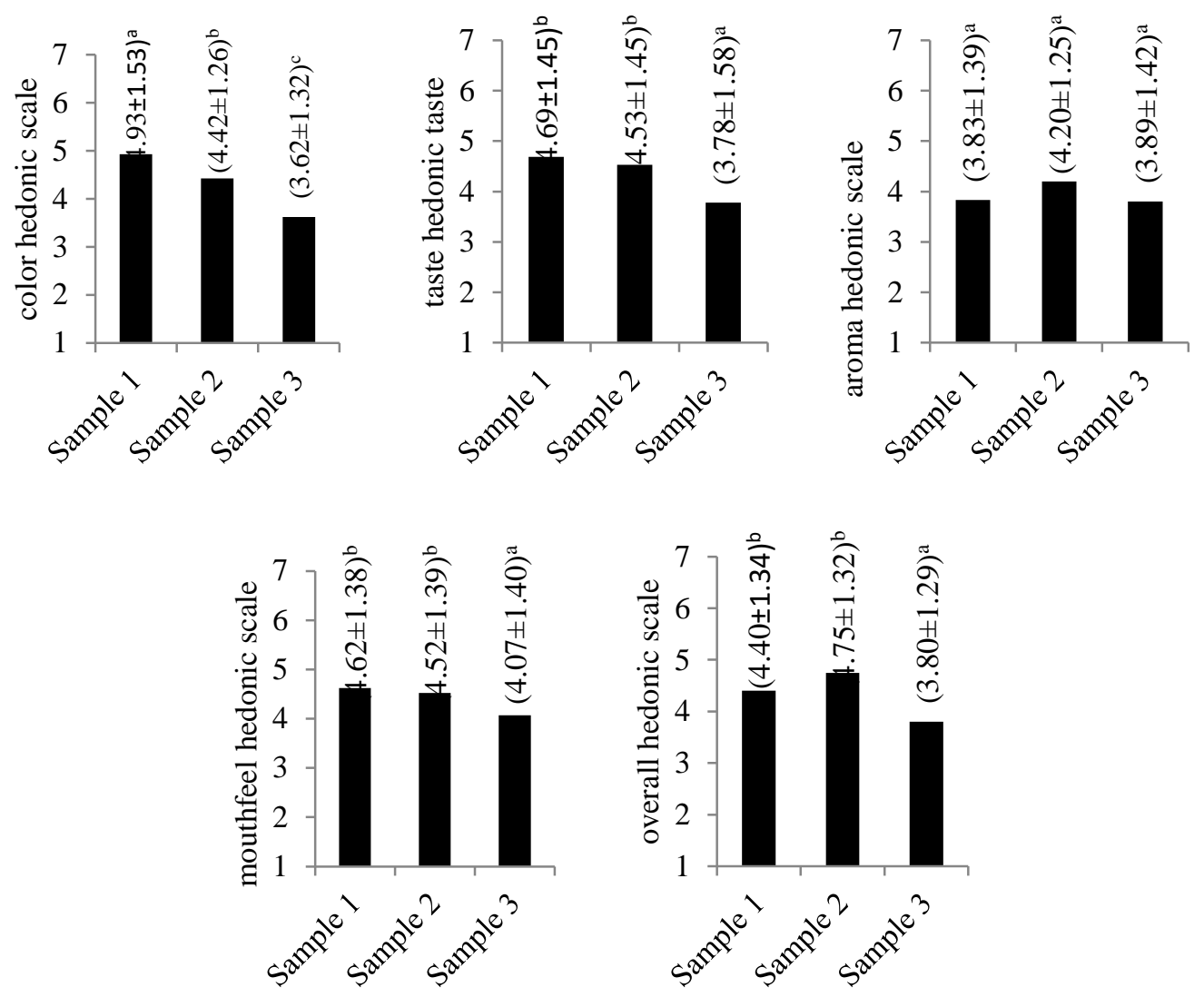

Figure 10. The result of hedonic test. Note: Hedonic scale (1=extremely dislike, $7=$ extremely like.) Sample $(1=100: 0$, $90^{\circ} \mathrm{C}, 0.025 \% \mathrm{XG} ; 2=75: 25,90^{\circ} \mathrm{C}, 0.050 \% \mathrm{XG} ; 3=50: 50,90^{\circ} \mathrm{C}, 0.100 \% \mathrm{XG}$ )

Table 8. Comparison the formulation with SNI 01-3830-1995

\begin{tabular}{lllll}
\hline Parameter & SNI Soy Milk & F1 & F2 & F3 \\
\hline Protein (\%) & Min.2.00 & 3.60 & 3.20 & 3.43 \\
Dietary Fiber (\%) & - & 5.11 & 4.46 & 4.34 \\
pH & $6.50-7.0$ & 6.78 & 6.51 & 6.60 \\
Total Solid (\%) & Min.11.50 & 12.24 & 11.56 & 12.01 \\
\hline
\end{tabular}

Formulation $1(\mathrm{~F} 1)=100: 0,90^{\circ} \mathrm{C}, 0.025 \% \mathrm{XG}$

Formulation $2(\mathrm{~F} 2)=75: 25,90^{\circ} \mathrm{C}, 0.050 \% X \mathrm{XG}$

Formulation $3(F 3)=50: 50,90^{\circ} \mathrm{C}, 0.100 \% X G$

Table 9. Proximate analysis of the most preferred formulation

\begin{tabular}{lc}
\hline \multicolumn{1}{c}{ Parameter } & Result \\
\hline Water (\%) & $88.46 \pm 0.04$ \\
Protein(\%) & $2.58 \pm 0.13$ \\
Fat $(\%)$ & $2.51 \pm 0.49$ \\
Ash(\%) & $0.28 \pm 0.01$ \\
Carbohydrate(\%) & $6.16 \pm 0.59$ \\
\hline
\end{tabular}




\section{Observation on Shelf Life Test}

Observations on shelf life test were carried out on a best EM and RBM functional beverage up to $\mathrm{pH}$ of less than 6.50. After storage in refrigerator for 14 days the $\mathrm{pH}$ declined. On day 1, pH 6.91 declined up to $\mathrm{pH} 6.54$ on day 14 , then on $15^{\text {th }}$ day $\mathrm{pH}$ become 6.45 . Consequently, it could be concluded that shelf life of EM and RBM functional drink was 14 days with good aroma and taste.

\section{CONCLUSION}

Beverage made from edamame bean and red beans contained dietary fiber $4.46 \%$ and adequate daily intake $17.84 \%$, which could be categorized as a "dietary fiber source" drink. Accordingly, it also could be categorized as functional drink. From the first stage of research, protein of EM and RBM functional drinks obtained between 1.74-3.60\%, the average $\mathrm{pH} 6.75$, the range of viscosity $48.8-70.8 \mathrm{cps}$, while the total solids varied from $7.95 \%$ to $17.91 \%$, as well as the optimum cooking temperature was $90{ }^{\circ} \mathrm{C}$. Second stage of the research obtained that Xanthan Gum was determined as appropriate stabilizer. Selection of RBM and EM functional beverage of test preferences was ratio of EM 75 to RBM 25 with $0.05 \%$ stabilizer addition. The shelf life of the drink in this research was 14 days. To improve the aroma, the drink could be added by vanilla flavor. In addition, the beans can be soaked with hot water before it is milled in order to remove the lipoxygenase enzymes that contribute the unpleasant aroma.

\section{REFERENCES}

1. Shurtleff, W., \& Aoyagi, A. (2000). Tofu \& soymilk production: a craft and technical manual (Vol. 2). Soyinfo Center.

2. USDA. 2016. Food Composition Databases.

3. Araújo, M. M., Fanaro, G. B., \& Villavicencio, A. L. C. H. (2013). Soybean and Isoflavones-From Farm to Fork. In Soybean-Bio-Active Compounds. InTech.

4. US Food and Drug Administration. (2008). Guidance for industry: a food labeling guide. Food and Drug Administration, Washington, DC, USA.

5. Badan Standarisasi Nasional. 1995. SNI 01-38301995: Susu Kedelai.

6. Sharma, B. R., Naresh, L., Dhuldhoya, N. C., Merchant, S. U., \& Merchant, U. C. (2006). Xanthan gum-A boon to food industry. Food promotion chronicle, 1(5), 27-30.

7. Kunaepah, U. 2008. Pengaruh lama fermentasi dan konsentrasi glukosa terhadap aktivitas antibakteri, polifenol total dan mutu kimia kefir susu kacang merah. Master thesis, Universitas Diponegoro.
8. Onuorah, C. E., A. O Adejare, dan N. S. Uhiara. 2007. Comparative physico-chemical evaluation of soymilk and soya cake produced by three different methods" Nigerian Food J. 25: 28-38

9. Angraini, A. dan Yunianta. 2015. Effect of temperature and duration of hydrolysis of papain enzyme on physical and organoleptic properties of milk edamame J Pangan Agro, 3(3): 1015-1025, 1017.

10. CAC. 2006. Guidelines for the use of nutrition claims: draft table of conditions for nutritient contents (Part b containing provisions on dietary fiber). 